\section{Age-related macular degeneration: a perspective on genetic studies}

\begin{abstract}
Aim Age-related macular degeneration (AMD) is a common macular disease in the developed world and recent studies have shown that specific genes may be associated with it and may contribute to a higher risk of developing AMD.

Objective Our objective was to review systematically recent publications related to the genetics of AMD and provide relevant information that would help both scientists and clinicians in advising patients.

Method A systematic search was performed on PubMed, Medline, and National Library of Medicine as well as ARVO abstracts using key words relevant to the genetic associations of
\end{abstract} AMD.

Results The most important genetic associations in AMD involved the complement factor $\mathrm{H}(\mathrm{CFH})$ gene, which showed that possession of the variant $\mathrm{Y} 402 \mathrm{H}$ polymorphism significantly increases the risk for AMD. Protective genes have also been identified such as those on either factor $B$ (BF or complement factor B (CFB)) or complement component 2 (C2) genes. The genes involved in inherited macular dystrophies such as ATP-binding cassette, subfamily A (ABC1), member 4 (ABCA4), vitelliform macular dystrophy (VMD2), tissue inhibitor of matrix metalloproteinase-3 (TIMP3), and EFEMP1 have yielded some important information but further confirmatory work has yet to establish a clear association with AMD.

Conclusion Patients with AMD possess specific genetic variants of the $C F H$ gene, which put them at a higher risk of developing the disease. Other unaffected individuals may possess certain protective genetic variants, which could prevent them from developing AMD. Further research will no doubt shed light on other such mechanisms and these will
N Patel, T Adewoyin and NV Chong

be useful in identifying possible direct targets for drugs or indirectly through modulation of the genes responsible for disease presentation. Eye (2008) 22, 768-776; doi:10.1038/sj.eye.6702844; published online 11 May 2007

Keywords: genetics; age-related macular degeneration; systemic review; complement factor $\mathrm{H}$

\section{Introduction}

Age-related macular degeneration (AMD) is a common macular disease affecting about $30 \%$ of adults aged 75 or older who have some signs of maculopathy, and about $6-8 \%$ of the individuals in this age group are afflicted with the advanced stages of this disease which causes the most severe visual loss. ${ }^{1}$ As the disease primarily impacts on central vision, it is the leading cause of blindness in people above 60 years of age and accounts for about $50 \%$ of blind registration. . $^{2,3}$

A number of epidemiological studies have implicated AMD as an inherited disease showing that family members are at increased risk of the disease. ${ }^{4,5}$ Results from twin and family-based studies have provided compelling evidence for a genetic basis for AMD. ${ }^{6-8}$ As it is a condition prevalent at old age, finding well-established family pedigrees is difficult. The inheritance is thought to be polygenic and environmental factors such as smoking, hypertension, and chronic inflammation are thought to play major roles in its pathogenesis. The emphasis on the genetic basis of AMD has increased in recent years. This systematic review was performed to look at the role of genes in AMD and to evaluate which particular genes play important roles in the inheritance of the disease so that accurate information can be displayed in a logical pattern for both clinicians and scientists. The information could be used to 
identify high-risk patients so that lifestyle behaviour such as smoking can be modified.

\section{Methods}

A detailed search using, PubMed, MEDLINE (1985 to August 2006), and EMBASE (1985 to August 2006) was performed. Conference abstracts (sessions related to AMD genetics and Inherited Macular Dystrophies) in ARVO 1975 to 2006 were analysed in detail looking for relevant published articles in this field.

\section{Discussion}

A number of studies including familial, twin-based, and other analyses have shown a strong genetic component in AMD. The work done by Seddon et al ${ }^{9}$ showed that prevalence among relatives was significantly higher compared to controls (23.7\% vs $11.6 \%$ ). Similar work by Klaver $e a^{10}$ showed that the odds ratios for siblings and offsprings of AMD patients were higher compared to siblings of controls. Several independent groups have examined studies comparing concordance rates in monozygotic vs dizygotic twins. ${ }^{11,12}$ These two larger studies showed that there is a substantial heritable component to AMD; however unique environmental factors also play an important role.

Researchers have carried out a number of linkage studies in an attempt to identify the genomic regions containing susceptibility loci for AMD. These studies were performed to evaluate whether genetic marker loci segregated independently of disease status within family pedigrees. In the last decade, the study of hereditary macular dystrophies such as Best's, Stargardt's, Sorsby's fundus, autosomal-dominant drusen- and peripherin/ $R D S$-related dystrophy has provided some clues to the pathogenesis of AMD. Many investigators have proposed that inherited macular dystrophies could be potential models for AMD. Once positional loci and function of the various genes from some of these inherited macular diseases were confirmed, more specific analysis was performed on AMD patients. Tables 1 and 2 show the various candidate genes tested with negative findings in the former and positive findings in the latter.

Studies of Sorsby's fundus dystrophy and the identification of the gene mutation for a tissue inhibitor of matrix metalloproteinase-3 (TIMP3) has not correlated with AMD. ${ }^{13}$ The identification of the ATP-binding cassette, subfamily A (ABC1), member 4 ( $A B C A 4)$ gene that encodes for a retinal rod/cone photoreceptor protein and its deletion results in Stargardt's macula dystrophy. Allikmets et $\mathrm{al}^{14}$ showed the presence of $A B C A 4$ polymorphisms in $3.4 \%$ of their total screened patients compared to $0.95 \%$ of controls. It has also been suggested
Table 1 Negative candidate gene screening in patients with AMD to date

\begin{tabular}{|c|c|c|}
\hline Site & Authors & Loci \\
\hline \multirow[t]{3}{*}{ Chromosome 1q } & Esfandiary et $a l^{55}$ & EPHX1, ADPRT1 \\
\hline & Hayashi et al ${ }^{56}$ & LXR2, LAMC1 \\
\hline & Conley et $a l^{57}$ & LAMC2, LAMB3, \\
\hline \multirow[t]{2}{*}{ Chromosome $2 \mathrm{p}$} & Stone $e t a l^{58}$ & $\begin{array}{l}\text { OCLM, RGS19, TGFB2 } \\
\text { EFEMP1 }\end{array}$ \\
\hline & Guymer et al ${ }^{59}$ & \\
\hline \multirow[t]{2}{*}{ Chromosome 2q } & Haines et $a l^{52}$ & IL1A \\
\hline & Stone et $a l^{19}$ & FIBULIN 2 \\
\hline Chromosome 3p & Esfandiary et al ${ }^{55}$ & GPX1 \\
\hline Chromosome $3 q$ & Kuehn et $a l^{60}$ & IMPG2 \\
\hline Chromosome $6 \mathrm{p}$ & Shastry et $a l^{61}$ & $R D S$ \\
\hline Chromosome 7 & Esfandiary $e t a l^{55}$ & AhR \\
\hline Chromosome 8p & Esfandiary et $a l^{55}$ & NAT2 \\
\hline Chromosome $10 q$ & Esfandiary et $a l^{55}$ & CYP2E1 \\
\hline Chromosome 11p & Esfandiary et $a l^{55}$ & CAT \\
\hline \multirow[t]{6}{*}{ Chromosome 11q } & Stone et $a l^{19}$ & FIBULIN 4 \\
\hline & Lotery et $a l^{17}$ & $V M D 2$ \\
\hline & Akimoto et al ${ }^{62}$ & \\
\hline & Seddon et $a l^{63}$ & \\
\hline & Allikmets et $a l^{16}$ & \\
\hline & Kramer et $a l^{64}$ & \\
\hline Chromosome $12 p$ & Haines et $a l^{52}$ & A2M, MSGT1 \\
\hline Chromosome $14 \mathrm{q}$ & Haines et $a l^{52}$ & $\mathrm{CKB}$ \\
\hline Chromosome $15 q$ & Esfandiary et $a l^{55}$ & CYP1A1, CY1A2 \\
\hline Chromosome $17 \mathrm{q}$ & Conley et $a l^{57}$ & APOH, ITGB4 \\
\hline \multirow[t]{3}{*}{ Chromosome $22 \mathrm{q}$} & Esfandiary et al $l^{55}$ & CYP2D6 \\
\hline & Stone et $a l^{19}$ & FIBULIN 1 \\
\hline & De La Paz et $a l^{13}$ & TIMP-3 \\
\hline
\end{tabular}

Abbreviations: AMD, age-related macular degeneration; TIMP3, tissue inhibitor of matrix metalloproteinase-3; VMD2, vitelliform macular dystrophy.

that heterozygotes for $A B C A 4$ mutations were predisposed to AMD but these results have been disputed in later studies. ${ }^{14,15}$ The role of $A B C A 4$ remains uncertain in AMD and the possibility that this gene causes a small number of AMD cases cannot be excluded. The protein bestrophin and its gene mutation is responsible for vitelliform macular dystrophy (VMD2, Best's disease), an early onset, autosomal, dominant macular degeneration characterized by the deposition of lipofuscin-like material within and below the retinal pigment epithelium but studies have shown a small, non-significant correlation with AMD. ${ }^{16,17}$

Malattia leventinese or Doyne honeycomb retinal dystrophy shares similar clinical and histological features to AMD and the gene (EFEMPI) responsible for the disease encodes for a member of the fibulin family (fibulin-3/SI-5/FBNL), a newly recognized group of extracellular matrix proteins. ${ }^{18}$ A recent study has shown that missense variations in the fibulin 5 gene were found in $1.7 \%$ of patients with AMD with many variations in other fibulin genes being found in these patients. ${ }^{19}$ This 
Table 2 Positive candidate gene screening for AMD genes

\begin{tabular}{|c|c|c|}
\hline Site & Authors & Loci \\
\hline Chromosome $1 \mathrm{p}$ & $\begin{array}{l}\text { Allikmets } e t a l^{14} \\
\text { Kuroiwa } e t a l^{65} \\
\text { Allikmets } \\
\text { Fuse } e t a l^{67} \\
\text { Rivera } e t a l^{68} \\
\text { Souied et } a l^{69} \\
\text { Guymer } \text { et }^{6} l^{70} \\
\text { Shroyer } e t a l^{71} \\
\text { Webster } e t a l^{72} \\
\text { Bernstein } e t a l^{73} \\
\text { Baum et } a l^{74} \\
\text { Schmidt } e t a l^{75}\end{array}$ & $A B C A 4(A B C R)$ \\
\hline \multirow[t]{2}{*}{ Chromosome 1q } & $\begin{array}{l}\text { Edwards } e t a l^{76} \\
\text { Haines } e t a l^{31} \\
\text { Klein } e t a l^{77} \\
\text { Hageman } \text { et } a l^{78} \\
\text { Zareparsi } \text { et }^{2} l^{29} \\
\text { Conley et } a l^{30} \\
\text { Jakobsdottir et } a l^{35} \\
\text { Souied et al } \\
\text { Magnusson } e t a l^{80}\end{array}$ & $\mathrm{CFH}$ \\
\hline & $\begin{array}{l}\text { Schultz et } a l^{81} \\
\text { Abecasis } e t a l^{82} \\
\text { Hayashi et } a l^{56} \\
\text { Iyengar et } a l^{83} \\
\text { Stone et } a l^{19} \\
\text { Conley et } a l^{57}\end{array}$ & $\begin{array}{l}\text { HEMICENTIN } \\
\text { (FIBULIN 6) }\end{array}$ \\
\hline Chromosome 3p & Tuo et $a l^{84}$ & CX3CR1 \\
\hline Chromosome $6 p$ & $\begin{array}{l}\text { Gold et } a l^{34} \\
\text { Goverdhan } e t a l^{48} \\
\text { Haines et } a l^{52} \\
\text { Churchill } e t a l^{85}\end{array}$ & $\begin{array}{l}B F \text { and } C 2 \\
H L A \\
V E G F\end{array}$ \\
\hline Chromosome 6q & $\begin{array}{l}\text { Ayyagari et } a l^{86} \\
\text { Conley et } a l^{57} \\
\text { Kimura et } a l^{87} \\
\text { Esfandiary et } a l^{55}\end{array}$ & $\begin{array}{l}\text { ELOVL4 } \\
\text { SOD2 }\end{array}$ \\
\hline Chromosome $7 q$ & $\begin{array}{l}\text { Ikeda et } a l^{88} \\
\text { Baird et } a l^{42} \\
\text { Esfandiary et } a l^{55}\end{array}$ & PON1 \\
\hline Chromosome $9 p$ & $\begin{array}{l}\text { Conley et } a l^{57} \\
\text { Haines et } a l^{52}\end{array}$ & VLDLR \\
\hline Chromosome $9 q$ & Zareparsi $e t a l^{29}$ & TLR4 \\
\hline Chromosome 10q & $\begin{array}{l}\text { Jakobsdottir et } a l^{35} \\
\text { Rivera } \text { et } a l^{36}\end{array}$ & $\begin{array}{l}\text { GRK5/PLEKHA1/ } \\
\text { LOC387715 }\end{array}$ \\
\hline $\begin{array}{l}\text { Chromosome } 12 p \\
\text { Chromosome } 14 q\end{array}$ & $\begin{array}{l}\text { Haines et } a l^{52} \\
\text { Stone } \text { et } a l^{19}\end{array}$ & $\begin{array}{l}\text { LRP6 } \\
\text { FIBULIN } 5\end{array}$ \\
\hline Chromosome 17q & $\begin{array}{l}\text { Hamdi et } a l^{89} \\
\text { Conley et } a l^{57} \\
\text { Haines et } a l^{52} \\
\text { Seddon et } a l^{90}\end{array}$ & ACE \\
\hline
\end{tabular}

Table 2 (Continued)

\begin{tabular}{lll}
\hline Site & Authors & Loci \\
\hline & $\begin{array}{l}\text { Souied } \text { et } a l^{40} \\
\text { Pang } \text { et } a l^{91} \\
\text { Simonelli } \text { et } a l^{92} \\
\text { Schmidt } \text { et } a l^{93}\end{array}$ & \\
Chromosome 19q & $\begin{array}{l}\text { Baird } \text { et } a l^{94} \\
\text { Gotoh } \text { et } a l^{45} \\
\text { Zareparsi } \text { et } a l^{43} \\
\text { Conley } \text { et } a l^{57}\end{array}$ & APOE \\
Wong et $a l^{95}$ & \\
Chromosome 20p & $\begin{array}{l}\text { Zurdel } \text { et } a l^{96} \\
\text { Chromosome 20q }\end{array}$ & CST3 \\
\hline Fiotti et $a l^{97}$ & MMP9
\end{tabular}

Abbreviations: $A B C A 4$, ATP-binding cassette, subfamily A (ABC1), member 4; AMD, age-related macular degeneration; $A P O E$, apolipoprotein $\mathrm{E}$; $B F$, factor $\mathrm{B} ; \mathrm{C2}$, complement component 2; $C F H$, complement factor $\mathrm{H}$; $H L A$, human leucocyte antigen; VEGF, vascular endothelial growth factor.

finding may be relevant to AMD pathogenesis as misfolding of the FBNL-5 protein may result in dysfunction at the extracellular matrix in Bruch's membrane. Reduced secretion of the mutant FBLN-5 protein seems to be important for AMD to develop in these patients. ${ }^{20}$ This could result in abnormal deposition as seen in drusen and consequent disinhibition of vascular endothelial growth factor (VEGF) resulting in CNV pathogenesis. ${ }^{21}$

The immune system has been implicated in pathogenesis of AMD for years from the work of Hageman and colleagues. ${ }^{22-24}$ Histological studies that have showed the presence of complement components both within drusen and along the RPE-choroid interface in AMD eyes. ${ }^{22}$ Its role in the pathogenesis of AMD has been confirmed recently by the identification of polymorphisms in the gene that encodes for complement factor $\mathrm{H}(\mathrm{CFH})$ in AMD patients. The complement system is part of the innate defence mechanism consisting of over 30 serum proteins involved as a cascade that results in the rapid delivery of activated enzymes which create micropores within foreign objects such as microbes resulting in cellular lysis and inflammation.

The $C F H$ is part of the alternative pathway and it is specifically involved with the inhibition of the cascade in combination with other proteins. It is thought that for some reason in AMD patients, abnormal regulation of the complement cascade occurs at a local level within Bruch's membrane and adjacent retinal pigment epithelial cells resulting in uncontrolled compliment activation and consequent drusen formation. ${ }^{25}$ Recent 
studies has shown that the presence of the at-risk haplotype increased the risk of AMD 2.7-fold and accounted for $50 \%$ of the attributable risk of AMD in that group. ${ }^{26,27}$ Another study has shown that individuals homozygous for the risk alleles (representing a tyrosine-histidine change at amino acid 402) have a 7.4-fold increased likelihood of AMD. ${ }^{28}$

These studies confirm an initial hypothesis, which established that chronic inflammation involving the complement pathway could contribute to disease progression. Using candidate gene screening, several different groups have found an association between the CFH gene and AMD in large numbers of patients. ${ }^{29,30}$ Another study has shown that possession of the variant Y402 H polymorphism significantly increases the risk for AMD with odds ratios between 2.45 and 5.57 and could explain approximately $43 \%$ of AMD in older adults. ${ }^{31}$ Table 3 shows a summary of the recent global papers on CFH and AMD containing the odds ratio and confidence intervals with each polymorphism.

A recent Japanese study showed that the $\mathrm{CFH}$ gene did not appear to be a primary hereditary contributor to AMD suggesting ethnic differences of AMD

phenotypes. ${ }^{32}$ Most of the studies that showed significant findings consisted of Caucasian populations; however, in Chinese patients, results on AMD patients has shown that the frequency of the $\mathrm{Y} 402 \mathrm{H}$ polymorphism is much lower in comparison and is associated with neovascular AMD. ${ }^{33}$ Gold et al ${ }^{34}$ examined two other factors involved in the complement cascade, factor B (BF) and complement component 2 (C2), for genetic variation in two independent cohorts. The results showed that $56 \%$ of the individuals who did not have AMD were in possession of the protective variant of either $C F H, B F$, or C2 gene compared to 74\% with AMD who lacked the protective variant. As shown in Table 4, the figures from this study indicate that possession of the specific $C 2$ and $B F$ polymorphisms may have a protective effect against AMD. An absence of these variations on the $C 2 / C F B$ genome may otherwise predispose patients to develop AMD. Other genes such as the LOC387715 on chromosome 10q26 are also thought to confer higher risks to developing $\mathrm{CNV}$ independent of the $\mathrm{CFH}$ gene. ${ }^{35,36}$ This gene is located in an extensive region of linkage disequilibrium, which encompasses other genes that show association with AMD and it is postulated that the causative mutation could be in a neighbouring gene ${ }^{37}$ (Table 5). Interestingly, Schimdt et al ${ }^{38}$ have shown that genetic susceptibility (such as a coding change (Ala69Ser) on the LOC387715 gene) coupled with a modifiable lifestyle factor such as cigarette smoking could confer a significantly higher risk of AMD than either factor alone.

Table 4 Odds risk ratios associated with $B F$ and $C 2$ variants showing a possible protective effect against AMD in those patients who possess these variations in this particular study

\begin{tabular}{lc}
\hline Gene $(S N P)$ & OR $(95 \% \mathrm{CI})$ \\
\hline C2 (rs9332739) & $0.36(0.23-0.56)$ \\
C2 (rs547154) & $0.44(0.33-0.60)$ \\
BF (rs4151667) & $0.36(0.23-0.56)$ \\
BF (rs641153) & $0.32(0.21-0.48)$
\end{tabular}

Abbreviations: AMD, age-related macular degeneration; $B F$, factor $B ; C 2$, complement component 2; $\mathrm{CI}$, confidence interval; $\mathrm{OR}$, odds risk ratios.

Table 3 A summary of the odds risk ratios (OR) associated with $\mathrm{Y} 402 \mathrm{H}$ in AMD from recent studies

\begin{tabular}{|c|c|c|c|c|}
\hline Study & Genotype & $\begin{array}{c}\text { Sample size } \\
\text { AMD }\end{array}$ & Control & OR $(95 \% C I)$ \\
\hline Columbia cohort* & $\mathrm{CC} / \mathrm{CT}$ & 549 & 272 & $2.25(1.79-2.75)$ \\
\hline Iowa cohort* & $\mathrm{CC} / \mathrm{CT}$ & 403 & 131 & $2.82(2.11-3.78)$ \\
\hline \multirow[t]{2}{*}{ (Massachusetts)* $^{*}$} & $\mathrm{CC}$ & 111 & 401 & $2.13(1.10-4.16)$ \\
\hline & $\mathrm{CT}$ & - & - & $1.46(1.05-2.04)$ \\
\hline \multirow[t]{2}{*}{ Magnusson (Iceland)* } & $\mathrm{CC} / \mathrm{CT}$ & 581 & 171 & $2.39(1.86-3.07)$ \\
\hline & $\mathrm{CC} / \mathrm{CT}$ & 322 & 203 & $2.14(1.66-2.75)^{*}$ \\
\hline \multirow[t]{2}{*}{ Souied (France)* } & $\mathrm{CC}$ & 141 & 91 & $6.93(3.11-15.46)$ \\
\hline & $\mathrm{CT}$ & - & - & $3.00(1.60-5.62)$ \\
\hline \multirow[t]{2}{*}{ Italy* } & $\mathrm{CC}$ & 104 & 131 & $3.9(1.9-8.2)$ \\
\hline & $\mathrm{CT}$ & - & - & $1.4(0.7-2.6)$ \\
\hline \multirow[t]{2}{*}{ Zareparsi (Michigan)* } & $\mathrm{CC}$ & 616 & 275 & $5.52(3.54-8.59)$ \\
\hline & $\mathrm{CT}$ & & & $4.36(3.13-6.08)$ \\
\hline \multirow[t]{2}{*}{ Sepp (UK)* } & $\mathrm{CC}$ & 443 & 262 & $6.3(3.8-10.4)$ \\
\hline & $\mathrm{CT}$ & - & - & - \\
\hline
\end{tabular}

Abbreviations: AMD, age-related macular degeneration; CI, confidence interval; OR, odds risk ratios.

It is important to note that the cases differ amongst the studies of all AMD patients including advanced AMD.

*Advanced AMD.

OR calculated using TT as a reference. 
Table 5 CNV risk associated with PLEKHA1/LOC387715 variants (Jakobsdottir et al)

\begin{tabular}{|c|c|}
\hline Gene (SNP) & OR $(95 \% C I)$ \\
\hline \multicolumn{2}{|l|}{ rs4146894 } \\
\hline Dominant (RR + RN) & $2.53(1.64-3.91)$ \\
\hline Recessive (RN) & $2.46(1.63-3.71)$ \\
\hline \multicolumn{2}{|l|}{ rs10490924 } \\
\hline Dominant $(\mathrm{RR}+\mathrm{RN})$ & $5.64(3.52-9.06)$ \\
\hline Recessive (RN) & $6.18(2.62-14.59)$ \\
\hline
\end{tabular}

Apolipoprotein E (ApoE) genotype was studied initially for its association with Alzheimer disease due to the presence of increase amyloid $\beta$-peptides deposition in cerebral cortex. ${ }^{39}$ The role of ApoE has also been investigated extensively to understand the aetiology of AMD. This polymorphic protein plays an important role in lipid metabolism and central nervous system lipid homeostasis and the presence of lipid in drusen has prompted these studies. Souied et $a l^{40}$ showed a reduced prevalence of the $\varepsilon 4$ allele in patients with exudative AMD as compared to a control sample and concluded that the $A p o E$ gene is a genetic protective factor identified in AMD. Other studies have shown the presence of $A p o E$ protein within AMD-associated deposits in the macula. ${ }^{41}$ Some studies have shown that $\varepsilon 4$ allele could be protective, or at the very least, delaying the age of diagnosis of disease, whereas the $\varepsilon 2$ allele appears to have a modifier effect by bringing forward the mean age of disease diagnosis. ${ }^{42,43}$ There are other studies which did not find a significant association between AMD development and ApoE allele frequency. ${ }^{44,45}$ Table 6 summarizes the findings of the odds ratios in AMD looking at ApoE2 and ApoE4 alleles in reference to ApoE3. The data shows that possession of ApoE4 may have a protective effect in comparison to ApoE2 with regard to development of AMD.

The role of inflammation and genetic predisposition reported in AMD may involve immune response gene such as human leucocyte antigen (HLA) polymorphisms that modulate susceptibility to AMD, HLA antigens are expressed both normally and in eyes affected with AMD and with intense $H L A$-DR immunoreactivity that has been demonstrated in both soft and hard drusens. ${ }^{46}$ Increased HLA class II immunoreactivity has been observed in the human retina affected with AMD and related to drusen formation. ${ }^{47}$ Genetic analysis of patients with AMD have revealed that there may be
Table 6 A summary table of the association between AMD showing the protective effect of the Apos4 against AMD in comparison to Apos2 with reference to Apos3

\begin{tabular}{|c|c|c|c|c|}
\hline Study & $\begin{array}{l}\text { Allele } \\
\text { carrier }\end{array}$ & $\begin{array}{c}\text { Sample size } \\
A M D\end{array}$ & Control & OR $(95 \% C I)$ \\
\hline Baird & $\varepsilon 2$ & 200 & 123 & $1.59(0.71-3.55)$ \\
\hline (Australia) & $\varepsilon 4$ & & & $0.65(0.37-1.13)$ \\
\hline Schmidt & $\varepsilon 2$ & 230 & 372 & $0.99(0.59-1.66)$ \\
\hline (Tennessee, USA) & $\varepsilon 4$ & & & $0.88(0.58-1.35)$ \\
\hline Klaver & $\varepsilon 2$ & 88 & 901 & $1.50(0.80-2.82)$ \\
\hline (Holland) & $\varepsilon 4$ & & & $0.43(0.21-0.88)$ \\
\hline Zareparsi & $\varepsilon 2$ & 632 & 206 & $1.12(0.63-2.00)^{\mathrm{a}}$ \\
\hline (Michigan, USA) & $\varepsilon 4$ & & & $0.55(0.37-0.82)$ \\
\hline
\end{tabular}

Abbreviations: AMD, age-related macular degeneration; $\mathrm{CI}$, confidence interval; OR, odds risk ratios.

${ }^{\text {aUnadjusted OR. }}$

relevant positive and negative associations between $H L A$ alleles and AMD, and these could influence the development of AMD through modulation of the choroidal immune function. ${ }^{48}$

\section{Conclusion}

These studies have confirmed that some affected patients may possess specific genetic variants of the CFH gene, which put them at a higher risk of developing the disease. Other unaffected individuals may possess certain protective genetic variants, which could prevent them from developing AMD. Modifiable factors such as smoking and body mass index (BMI) are very important as they confer a higher risk of developing $\mathrm{CNV}$ in the presence of high-risk alleles. ${ }^{49}$ It is imperative to clarify that the mechanism of disease development can be difficult in complex diseases such as AMD, and these studies have helped in our understanding of pathological findings and genetic predispositions. From previous experience, screening has been important in prevention, early detection, and prompt treatment such as in diabetes. Using the same concept in AMD, we know that genetic factors play an important part as discussed previously and although mass screening in local populations is not indicated in AMD, there may be sufficient evidence to screen familial cases initially using genetic laboratory tests for the $C F H, C 2 / B F, L O C$, and $A p o E$ polymorphisms. These tests are in fact inexpensive to perform and could be readily made available in local laboratories (actual costs for genotyping a DNA sample by Taqman assay could be as less as 28 pence. Identification of higher risk cases can then be used to inform patients of their potential risk of developing the disease and advised to implement changes in their lifestyle such as lowering BMI or cessation of smoking. It 
is important to note here that there may not be sufficient evidence yet to suggest that adjusting these modifiable risk factors will influence future risk of developing AMD in the presence of these genetic polymorphisms.

New treatments of neovascular AMD such as Ranibizumab and Pegaptanib have shown promising results so far. ${ }^{50,51}$ It is feasible to assume that patients will respond differently to these new drugs due to inherent genetic influences which may need to be investigated further. These drugs were designed specifically as anti-VEGF therapy following extensive laboratory research. (VEGF) is an endothelial cell-specific mitogen that promotes angiogenesis and is a potent mediator of vascular permeability. Studies on diseases that involve inflammation and angiogenesis such as cancer, sarcoidosis, and more recently AMD have revealed VEGF polymorphisms that could put patients at higher or lower risks of developing the disease. ${ }^{52-54}$ Further research would no doubt shed light on other such mechanisms and these would be useful directly in identifying possible direct targets for drugs or indirectly through modulation of the genes responsible for disease presentation.

\section{References}

1 Friedman DS, O'Colmain BJ, Munoz B, Tomany SC, McCarty C, de Jong PT et al. Prevalence of age-related macular degeneration in the United States. Arch Ophthalmol 2004; 122(4): 564-572.

2 Owen CG, Fletcher AE, Donoghue M, Rudnicka AR. How big is the burden of visual loss caused by age related macular degeneration in the United Kingdom? $\mathrm{Br} J$ Ophthalmol 2003; 87(3): 312-317.

3 la Cour M, Kiilgaard JF, Nissen MH. Age-related macular degeneration: epidemiology and optimal treatment. Drugs Aging 2002; 19(2): 101-133.

4 Smith W, Mitchell P. Family history and age-related maculopathy: the Blue Mountains Eye Study. Aust N Z J Ophthalmol 1998; 26(3): 203-206.

5 Hyman L, Neborsky R. Risk factors for age-related macular degeneration: an update. Curr Opin Ophthalmol 2002; 13(3): 171-175.

6 Meyers SM. A twin study on age-related macular degeneration. Trans Am Ophthalmol Soc 1994; 92: 775-843.

7 Klein ML, Francis PJ. Genetics of age-related macular degeneration. Ophthalmol Clin North Am 2003; 16(4): 567-574.

8 Seddon JM, Santangelo SL, Book K, Chong S, Cote J. A genomewide scan for age-related macular degeneration provides evidence for linkage to several chromosomal regions. Am J Hum Genet 2003; 73(4): 780-790.

9 Seddon JM, Ajani UA, Mitchell BD. Familial aggregation of age-related maculopathy. Am J Ophthalmol 1997; 123(2): 199-206.

10 Klaver CC, Wolfs RC, Assink JJ, van Duijn CM, Hofman A, de Jong PT. Genetic risk of age-related maculopathy. Population-based familial aggregation study. Arch Ophthalmol 1998; 116(12): 1646-1651.
11 Seddon JM, Cote J, Page WF, Aggen SH, Neale MC. The US twin study of age-related macular degeneration: relative roles of genetic and environmental influences. Arch Ophthalmol 2005; 123(3): 321-327.

12 Hammond CJ, Webster AR, Snieder H, Bird AC, Gilbert CE, Spector TD. Genetic influence on early age-related maculopathy: a twin study. Ophthalmology 2002; 109(4): 730736.

13 De La Paz MA, Pericak-Vance MA, Lennon F, Haines JL, Seddon JM. Exclusion of TIMP3 as a candidate locus in age-related macular degeneration. Invest Ophthalmol Vis Sci 1997; 38(6): 1060-1065.

14 Allikmets R, Shroyer NF, Singh N, Seddon JM, Lewis RA, Bernstein PS et al. Mutation of the Stargardt disease gene (ABCR) in age-related macular degeneration. Science 1997; 277(5333): 1805-1807.

15 Stone EM, Webster AR, Vandenburgh K, Streb LM, Hockey RR, Lotery AJ et al. Allelic variation in ABCR associated with Stargardt disease but not age-related macular degeneration. Nat Genet 1998; 20(4): 328-329.

16 Allikmets R, Seddon JM, Bernstein PS, Hutchinson A, Atkinson A, Sharma $S$ et al. Evaluation of the Best disease gene in patients with age-related macular degeneration and other maculopathies. Hum Genet 1999; 104(6): 449-453.

17 Lotery AJ, Munier FL, Fishman GA, Weleber RG, Jacobson SG, Affatigato LM et al. Allelic variation in the VMD2 gene in best disease and age-related macular degeneration. Invest Ophthalmol Vis Sci 2000; 41(6): 1291-1296.

18 Marmorstein L. Association of EFEMP1 with malattia leventinese and age-related macular degeneration: a minireview. Ophthalmic Genet 2004; 25(3): 219-226.

19 Stone EM, Braun TA, Russell SR, Kuehn MH, Lotery AJ, Moore PA et al. Missense variations in the fibulin 5 gene and age-related macular degeneration. $N$ Engl J Med 2004; 351(4): 346-353.

20 Lotery AJ, Baas D, Ridley C, Jones RP, Klaver CC, Stone E et al. Reduced secretion of fibulin 5 in age-related macular degeneration and cutis laxa. Hum Mutat 2006; 27(6): 568-574.

21 Johnson LV, Anderson DH. Age-related macular degeneration and the extracellular matrix. $N$ Engl J Med 2004; 351(4): 320-322.

22 Hageman GS, Luthert PJ, Victor Chong NH, Johnson LV, Anderson DH, Mullins RF. An integrated hypothesis that considers drusen as biomarkers of immune-mediated processes at the RPE-Bruch's membrane interface in aging and age-related macular degeneration. Prog Retin Eye Res 2001; 20(6): 705-732.

23 Johnson LV, Leitner WP, Staples MK, Anderson DH Complement activation and inflammatory processes in Drusen formation and age related macular degeneration. Exp Eye Res 2001; 73(6): 887-896.

24 Mullins RF, Russell SR, Anderson DH, Hageman GS. Drusen associated with aging and age-related macular degeneration contain proteins common to extracellular deposits associated with atherosclerosis, elastosis, amyloidosis, and dense deposit disease. FASEB J 2000; 14(7): 835-846.

25 Sivaprasad S, Chong NV. The complement system and age-related macular degeneration. Eye 2006; 20(8): 867-872.

26 Hageman GS, Anderson DH, Johnson LV, Hancox LS, Taiber AJ, Hardisty LI et al. A common haplotype in the complement regulatory gene factor $\mathrm{H}(\mathrm{HF} 1 / \mathrm{CFH})$ predisposes individuals to age-related macular 
degeneration. Proc Natl Acad Sci USA 2005; 102(20): 7227-7232.

27 Edwards AO, Ritter Iii R, Abel KJ, Manning A, Panhuysen C, Farrer LA. Complement factor H polymorphism and age-related macular degeneration. Science 2005; 308: 421-424.

28 Klein RJ, Zeiss C, Chew EY, Tsai JY, Sackler RS, Haynes C et al. Complement factor $\mathrm{H}$ polymorphism in age-related macular degeneration. Science 2005; 308: 385-389.

29 Zareparsi S, Branham KE, Li M, Shah S, Klein RJ, Ott J et al. Strong association of the $\mathrm{Y} 402 \mathrm{H}$ variant in complement factor $\mathrm{H}$ at $1 \mathrm{q} 32$ with susceptibility to age-related macular degeneration. Am J Hum Genet 2005; 77(1): 149-153.

30 Conley YP, Thalamuthu A, Jakobsdottir J, Weeks DE, Mah T, Ferrell RE et al. Candidate gene analysis suggests a role for fatty acid biosynthesis and regulation of the complement system in the etiology of age-related maculopathy 10.1093/ hmg/ddi204. Hum Mol Genet 2005; 14(14): 1991-2002.

31 Haines JL, Hauser MA, Schmidt S, Scott WK, Olson LM, Gallins $\mathrm{P}$ et al. Complement factor $\mathrm{H}$ variant increases the risk of age-related macular degeneration. Science 2005; 308(5720): 419-421.

32 Gotoh N, Yamada R, Hiratani H, Renault V, Kuroiwa S, Monet $\mathrm{M}$ et al. No association between complement factor $\mathrm{H}$ gene polymorphism and exudative age-related macular degeneration in Japanese. Hum Genet 2006; 120: 1-5.

33 Lau LI, Chen SJ, Cheng CY, Yen MY, Lee FL, Lin MW et al. Association of the Y402 H Polymorphism in Complement Factor H Gene and Neovascular Age-Related Macular Degeneration in Chinese Patients. Invest Ophthalmol Vis Sci 2006; 47(8): 3242-3246.

34 Gold B, Merriam JE, Zernant J, Hancox LS, Taiber AJ, Gehrs $\mathrm{K}$ et al. Variation in factor B (BF) and complement component 2 (C2) genes is associated with age-related macular degeneration. Nat Genet 2006; 38(4): 458-462.

35 Jakobsdottir J, Conley YP, Weeks DE, Mah TS, Ferrell RE, Gorin MB. Susceptibility genes for age-related maculopathy on chromosome 10q26. Am J Hum Genet 2005; 77(3): 389-407.

36 Rivera A, Fisher SA, Fritsche LG, Keilhauer CN, Lichtner P, Meitinger T et al. Hypothetical LOC387715 is a second major susceptibility gene for age-related macular degeneration, contributing independently of complement factor $\mathrm{H}$ to disease risk. Hum Mol Genet 2005; 14(21): 3227-3236.

37 Marx J. Gene offers insight into macular degeneration. Science 2006; 314(5798): 405.

38 Schmidt S, Hauser MA, Scott WK, Postel EA, Agarwal A, Gallins $P$ et al. Cigarette smoking strongly modifies the association of LOC387715 and age-related macular degeneration. Am J Hum Genet 2006; 78(5): 852-864.

39 Schmechel DE, Saunders AM, Strittmatter WJ, Crain BJ, Hulette CM, Joo SH et al. Increased amyloid beta-peptide deposition in cerebral cortex as a consequence of apolipoprotein E genotype in late-onset Alzheimer disease. Proc Natl Acad Sci USA 1993; 90(20): 9649-9653.

40 Souied EH, Benlian P, Amouyel P, Feingold J, Lagarde JP, Munnich A et al. The $\varepsilon 4$ allele of the apolipoprotein $\mathrm{E}$ gene as a potential protective factor for exudative age-related macular degeneration. Am J Ophthalmol 1998; 125(3): 353-359.

41 Klaver CC, Kliffen M, van Duijn CM, Hofman A, Cruts M, Grobbee DE et al. Genetic association of apolipoprotein E with age-related macular degeneration. Am J Hum Genet 1998; 63(1): 200-206.
42 Baird PN, Chu D, Guida E, Vu HT, Guymer R. Association of the M55L and Q192R paraoxonase gene polymorphisms with age-related macular degeneration. Am J Ophthalmol 2004; 138(4): 665-666.

43 Zareparsi S, Reddick AC, Branham KE, Moore KB, Jessup L, Thoms $\mathrm{S}$ et al. Association of apolipoprotein E alleles with susceptibility to age-related macular degeneration in a large cohort from a single center. Invest Ophthalmol Vis Sci 2004; 45(5): 1306-1310.

44 Nowak M, Swietochowska E, Szapska B, Marek B, Wielkoszynski T, Koziol $\mathrm{H}$ et al. The apolipoprotein E polymorphism in age related macular degeneration]. Klin Oczna 2004; 106(Suppl 3): 427-428.

45 Gotoh N, Kuroiwa S, Kikuchi T, Arai J, Arai S, Yoshida N et al. Apolipoprotein E polymorphisms in Japanese patients with polypoidal choroidal vasculopathy and exudative age-related macular degeneration. Am J Ophthalmol 2004; 138(4): 567-573.

46 Mullins RF, Russell SR, Anderson DH, Hageman GS. Drusen associated with aging and age-related macular degeneration contain proteins common to extracellular deposits associated with atherosclerosis, elastosis, amyloidosis, and dense deposit disease. FASEB J 2000; 14(7): 835-846.

47 Penfold P, Liew S, Madigan M, Provis J. Modulation of major histocompatibility complex class II expression in retinas with age-related macular degeneration. Invest Ophthalmol Vis Sci 1997; 38(10): 2125-2133.

48 Goverdhan SV, Howell MW, Mullins RF, Osmond C, Hodgkins PR, Self J et al. Association of HLA Class I and Class II polymorphisms with age-related macular degeneration 10.1167/iovs.04-0928. Invest Ophthalmol Vis Sci 2005; 46(5): 1726-1734.

49 Seddon JM, George S, Rosner B, Klein ML. CFH gene variant, $\mathrm{Y} 402 \mathrm{H}$, and smoking, body mass index, environmental associations with advanced age-related macular degeneration. Hum Hered 2006; 61(3): 157-165.

50 Suganthalakshmi B, Anand R, Kim R, Mahalakshmi R, Karthikprakash S, Namperumalsamy $P$ et al. Association of VEGF and eNOS gene polymorphisms in type 2 diabetic retinopathy. Mol Vis 2006; 12: 336-341.

51 Rosenfeld PJ, Heier JS, Hantsbarger G, Shams N. Tolerability and efficacy of multiple escalating doses of ranibizumab (Lucentis) for neovascular age-related macular degeneration. Ophthalmology 2006; 113(4): 632 e1.

52 Haines JL, Schnetz-Boutaud N, Schmidt S, Scott WK, Agarwal A, Postel EA et al. Functional candidate genes in age-related macular degeneration: significant association with VEGF, VLDLR, and LRP6. Invest Ophthalmol Vis Sci 2006; 47(1): 329-335.

53 Lu H, Shu XO, Cui Y, Kataoka N, Wen W, Cai Q et al. Association of genetic polymorphisms in the VEGF gene with breast cancer survival. Cancer Res 2005; 65(12): 5015-5019.

54 Morohashi K, Takada T, Omori K, Suzuki E, Gejyo F. Vascular endothelial growth factor gene polymorphisms in Japanese patients with sarcoidosis 10.1378/chest.123.5.1520. Chest 2003; 123(5): 1520-1526.

55 Esfandiary H, Chakravarthy U, Patterson C, Young I, Hughes AE. Association study of detoxification genes in age related macular degeneration. Br J Ophthalmol 2005; 89(4): 470-474. 
56 Hayashi M, Merriam JE, Klaver CC, Zernant J, Bergen AA, Smith RT et al. Evaluation of the ARMD1 locus on 1q25-31 in patients with age-related maculopathy: genetic variation in laminin genes and in exon 104 of HEMICENTIN-1. Ophthalmic Genet 2004; 25(2): 111-119.

57 Conley YP, Thalamuthu A, Jakobsdottir J, Weeks DE, Mah T, Ferrell RE et al. Candidate gene analysis suggests a role for fatty acid biosynthesis and regulation of the complement system in the etiology of age-related maculopathy. Hum Mol Genet 2005; 14(14): 1991-2002.

58 Stone EM, Lotery AJ, Munier FL, Heon E, Piguet B, Guymer RH et al. A single EFEMP1 mutation associated with both Malattia Leventinese and Doyne honeycomb retinal dystrophy. Nat Genet 1999; 22(2): 199-202.

59 Guymer RH, McNeil R, Cain M, Tomlin B, Allen PJ, Dip CL et al. Analysis of the Arg345Trp disease-associated allele of the EFEMP1 gene in individuals with early onset drusen or familial age-related macular degeneration. Clin Exp Ophthalmol 2002; 30(6): 419-423.

60 Kuehn MH, Stone EM, Hageman GS. Organization of the human IMPG2 gene and its evaluation as a candidate gene in age-related macular degeneration and other retinal degenerative disorders. Invest Ophthalmol Vis Sci 2001; 42(13): 3123-3129.

61 Shastry BS, Trese MT. Evaluation of the peripherin/RDS gene as a candidate gene in families with age-related macular degeneration. Ophthalmologica 1999; 213(3): 165-170.

62 Akimoto A, Akimoto M, Kuroiwa S, Kikuchi T, Yoshimura $\mathrm{N}$. Lack of association of mutations of the bestrophin gene with age-related macular degeneration in non-familial Japanese patients. Graefes Arch Clin Exp Ophthalmol 2001; 239(1): 66-68

63 Seddon JM, Afshari MA, Sharma S, Bernstein PS, Chong S, Hutchinson A et al. Assessment of mutations in the Best macular dystrophy (VMD2) gene in patients with adultonset foveomacular vitelliform dystrophy, age-related maculopathy, and bull's-eye maculopathy. Ophthalmology 2001; 108(11): 2060-2067.

64 Kramer F, White K, Pauleikhoff D, Gehrig A, Passmore L, Rivera A et al. Mutations in the VMD2 gene are associated with juvenile-onset vitelliform macular dystrophy (Best disease) and adult vitelliform macular dystrophy but not age-related macular degeneration. Eur J Hum Genet 2000; 8(4): 286-292.

65 Kuroiwa S, Kojima H, Kikuchi T, Yoshimura N. ATP binding cassette transporter retina genotypes and age related macular degeneration: an analysis on exudative non-familial Japanese patients. Br J Ophthalmol 1999; 83(5): 613-615.

66 Allikmets R. Further evidence for an association of ABCR alleles with age-related macular degeneration. The International ABCR Screening Consortium. Am J Hum Genet 2000; 67(2): 487-491.

67 Fuse N, Suzuki T, Wada Y, Yoshida M, Shimura M, Abe T et al. Molecular genetic analysis of ABCR gene in Japanese dry form age-related macular degeneration. Jpn J Ophthalmol 2000; 44(3): 245-249.

68 Rivera A, White K, Stohr H, Steiner K, Hemmrich N, Grimm $\mathrm{T}$ et al. A comprehensive survey of sequence variation in the ABCA4 (ABCR) gene in Stargardt disease and age-related macular degeneration. Am J Hum Genet 2000; 67(4): 800-813.

69 Souied EH, Ducroq D, Rozet JM, Gerber S, Perrault I, Munnich $\mathrm{A}$ et al. ABCR gene analysis in familial exudative age-related macular degeneration. Invest Ophthalmol Vis Sci 2000; 41(1): 244-247.

70 Guymer RH, Heon E, Lotery AJ, Munier FL, Schorderet DF, Baird PN et al. Variation of codons 1961 and 2177 of the Stargardt disease gene is not associated with age-related macular degeneration. Arch Ophthalmol 2001; 119(5): 745-751.

71 Shroyer NF, Lewis RA, Yatsenko AN, Wensel TG, Lupski JR. Cosegregation and functional analysis of mutant ABCR (ABCA4) alleles in families that manifest both Stargardt disease and age-related macular degeneration. Hum Mol Genet 2001; 10(23): 2671-2678.

72 Webster AR, Heon E, Lotery AJ, Vandenburgh K, Casavant TL, Oh KT et al. An analysis of allelic variation in the ABCA4 gene. Invest Ophthalmol Vis Sci 2001; 42(6): 1179-1189.

73 Bernstein PS, Leppert M, Singh N, Dean M, Lewis RA, Lupski JR et al. Genotype-phenotype analysis of ABCR variants in macular degeneration probands and siblings. Invest Ophthalmol Vis Sci 2002; 43(2): 466-473.

74 Baum L, Chan WM, Li WY, Lam DS, Wang PB, Pang CP. ABCA4 sequence variants in Chinese patients with age-related macular degeneration or Stargardt's disease. Ophthalmologica 2003; 217(2): 111-114.

75 Schmidt S, Postel EA, Agarwal A, Allen Jr IC, Walters SN, De la Paz MA et al. Detailed analysis of allelic variation in the ABCA4 gene in age-related maculopathy. Invest Ophthalmol Vis Sci 2003; 44(7): 2868-2875.

76 Edwards AO, Ritter III R, Abel KJ, Manning A, Panhuysen C, Farrer LA. Complement factor H polymorphism and age-related macular degeneration. Science 2005; 308(5720): 421-424

77 Klein RJ, Zeiss C, Chew EY, Tsai JY, Sackler RS, Haynes C et al. Complement factor $\mathrm{H}$ polymorphism in age-related macular degeneration. Science 2005; 308(5720): 385-389.

78 Hageman GS, Anderson DH, Johnson LV, Hancox LS, Taiber AJ, Hardisty LI et al. From The Cover: A common haplotype in the complement regulatory gene factor $\mathrm{H}$ (HF1/CFH) predisposes individuals to age-related macular degeneration 10.1073/pnas.0501536102. Proc Natl Acad Sci USA 2005; 102(20): 7227-7232.

79 Souied EH, Leveziel N, Richard F, Dragon-Durey MA, Coscas G, Soubrane G et al. Y402 H complement factor H polymorphism associated with exudative age-related macular degeneration in the French population. Mol Vis 2005; 11: 1135-1140.

80 Magnusson KP, Duan S, Sigurdsson H, Petursson H, Yang Z, Zhao Yet al. CFH Y402 H confers similar risk of soft drusen and both forms of advanced AMD. PLoS Med 2006; 3(1): e5.

81 Schultz DW, Klein ML, Humpert AJ, Luzier CW, Persun V, Schain $\mathrm{M}$ et al. Analysis of the ARMD1 locus: evidence that a mutation in HEMICENTIN-1 is associated with agerelated macular degeneration in a large family. Hum Mol Genet 2003; 12(24): 3315-3323.

82 Abecasis GR, Yashar BM, Zhao Y, Ghiasvand NM, Zareparsi S, Branham KE et al. Age-related macular degeneration: a high-resolution genome scan for susceptibility loci in a population enriched for late-stage disease. Am J Hum Genet 2004; 74(3): 482-494.

83 Iyengar SK, Song D, Klein BE, Klein R, Schick JH, Humphrey $\mathrm{J}$ et al. Dissection of genomewide-scan data in extended families reveals a major locus and oligogenic 
susceptibility for age-related macular degeneration. Am I Hum Genet 2004; 74(1): 20-39.

84 Tuo J, Smith BC, Bojanowski CM, Meleth AD, Gery I, Csaky KG et al. The involvement of sequence variation and expression of CX3CR1 in the pathogenesis of age-related macular degeneration. Faseb J 2004; 18(11): 1297-1299.

85 Churchill AJ, Carter JG, Lovell HC, Ramsden C, Turner SJ, Yeung A et al. VEGF polymorphisms are associated with neovascular age-related macular degeneration. Hum Mol Genet 2006; 15(19): 2955-2961.

86 Ayyagari R, Zhang K, Hutchinson A, Yu Z, Swaroop A, Kakuk LE et al. Evaluation of the ELOVL4 gene in patients with age-related macular degeneration. Ophthal Genet 2001; 22(4): 233-239.

87 Kimura K, Isashiki Y, Sonoda S, Kakiuchi-Matsumoto T, Ohba N. Genetic association of manganese superoxide dismutase with exudative age-related macular degeneration. Am J Ophthalmol 2000; 130(6): 769-773.

88 Ikeda T, Obayashi H, Hasegawa G, Nakamura N, Yoshikawa T, Imamura $\mathrm{Y}$ et al. Paraoxonase gene polymorphisms and plasma oxidized low-density lipoprotein level as possible risk factors for exudative age-related macular degeneration. Am J Ophthalmol 2001; 132(2): 191-195.

89 Hamdi HK, Reznik J, Castellon R, Atilano SR, Ong JM, Udar $\mathrm{N}$ et al. Alu DNA polymorphism in ACE gene is protective for age-related macular degeneration. Biochem Biophys Res Commun 2002; 295(3): 668-672.
90 Gorin MB, Breitner JC, De Jong PT, Hageman GS, Klaver CC, Kuehn MH et al. The genetics of age-related macular degeneration. Mol Vis 1999; 5: 29.

91 Pang CP, Baum L, Chan WM, Lau TC, Poon PM, Lam DS. The apolipoprotein $\mathrm{E} \varepsilon 4$ allele is unlikely to be a major risk factor of age-related macular degeneration in Chinese. Ophthalmologica 2000; 214(4): 289-291.

92 Simonelli F, Margaglione M, Testa F, Cappucci G, Manitto MP, Brancato R et al. Apolipoprotein E polymorphisms in age-related macular degeneration in an Italian population. Ophthal Res 2001; 33(6): 325-328.

93 Schmidt S, Klaver C, Saunders A, Postel E, De La Paz M, Agarwal A et al. A pooled case-control study of the apolipoprotein E (APOE) gene in age-related maculopathy. Ophthalmic Genet 2002; 23(4): 209-223.

94 Baird PN, Guida E, Chu DT, Vu HT, Guymer RH. The $\varepsilon 2$ and $\varepsilon 4$ alleles of the apolipoprotein gene are associated with agerelated macular degeneration. Invest Ophthalmol Vis Sci 2004; 45(5): 1311-1315

95 Wong TY, Shankar A, Klein R, Bray MS, Couper DJ, Klein BE et al. Apolipoprotein E gene and early age-related maculopathy: the Atherosclerosis Risk in Communities Study. Ophthalmology 2006; 113(2): 255-259.

96 Zurdel J, Finckh U, Menzer G, Nitsch RM, Richard G. CST3 genotype associated with exudative age related macular degeneration. Br J Ophthalmol 2002; 86(2): 214-219.

97 Fiotti N, Pedio M, Battaglia Parodi M, Altamura N, Uxa L, Guarnieri G et al. MMP-9 microsatellite polymorphism and susceptibility to exudative form of age-related macular degeneration. Genet Med 2005; 7(4): 272-277. 